\title{
Mesoscale physical processes and the distribution and composition of ichthyoplankton on the southern Brazilian shelf break
}

\section{BÁRBARA CRISTIE FRANCO, $, 1,2$ JOSÉ HENRIQUE MUELBERT ${ }^{1, *}$ AND MAURICIO MAGALHÃES MATA ${ }^{2}$}

${ }^{1}$ Departamento de Oceanografia, Fundação Universidade Federal do Rio Grande, Caixa Postal 474, 96201-900 Rio Grande, RS, Brazil

${ }^{2}$ Departamento de Física, Fundação Universidade Federal do Rio Grande, Caixa Postal 474, 96201-900 Rio Grande, RS, Brazil

\begin{abstract}
The southern Brazilian shelf supports the largest fish stocks in the country, and studies on physical-biological processes in the ecology of ichthyoplankton have been recommended to provide a better understanding of the variability of the recruitment of fishing resources. This study is the first to examine the influence of mesoscale physical processes on the distribution of early life stages of fish in this shelf-break region. Collections of fish eggs and larvae and measurements of temperature and salinity were made at 13 stations along cross-shelf transects in December 1997. Myctophidae, Bregmacerotidae, Clupeidae, Synodontidae and Engraulidae were the most abundant larvae in the northern region, while Engraulidae and Bregmacerotidae prevailed further south. In situ hydrographic data, NOAA/AVHRR images and merged TOPEX/POSEIDON + ERS-1/2 satellite altimetry taken during the cruise revealed an anticyclonic eddy dominating the shelf around $31^{\circ} \mathrm{S}$. Larval fish abundance was lower at the centre of this feature, suggesting that the eddy advected poorer offshore waters of tropical origin towards the inner shelf-concentrating the larvae around the eddy.
\end{abstract}

Key words: Brazil Current, eddies, ichthyoplankton, mesoscale processes, satellite altimetry, sea-surface temperature, shelf break, south-western Atlantic

*Correspondence. e-mail: docjhm@furg.br

Received 30 June 2004

Revised version accepted 16 December 2004

(c) 2006 Blackwell Publishing Ltd.

\section{INTRODUCTION}

The southern Brazilian shelf (SBS) is part of the western boundary margin of the South Atlantic Ocean, delimited to the north by Santa Marta Cape $\left(28^{\circ} \mathrm{S} ; 48^{\circ} \mathrm{W}\right)$ and to the south by Arroio Chuí $\left(33^{\circ} \mathrm{S}\right.$; $\left.53^{\circ} \mathrm{W}\right)$. This coastal region is associated with the largest fish stocks in Brazil (e.g. Haimovici et al., 1989; Krug and Haimovici, 1991), presumably due to high phytoplankton biomass sustained by nutrient inputs from continental runoff and shelf-break upwelling (Ciotti et al., 1995). Initial studies have demonstrated the relative importance of the interaction between physical and biological processes in the ecology of ichthyoplankton in this region (Matsuura and Kitahara, 1995; Muelbert and Sinque, 1996). To better understand the factors affecting fishery recruitment variability in the SBS, additional biophysical research has been recommended (Castello and Haimovici, 1991; Heath, 1992; Hunter and Alheit, 1997).

The Brazil Current (BC) is the western branch of the South Atlantic Ocean subtropical gyre (e.g. Peterson and Stramma, 1991), and is also the boundary current which influences the outer SBS. Western boundary currents are known to exert a strong influence on outer shelf dynamics over a period of several days due to frontal eddies and meanders (Loder et al., 1998). The large southward transport of the BC in the region and its associated variability may be a critical factor contributing to the production of warm core eddies, as observed in AVHRR imagery (Goni et al., 1996). In situ measurements and TOPEX/POSEIDON $(\mathrm{T} / \mathrm{P})$ altimetry of the south-western Atlantic region reveal eddies developing as far north as $32^{\circ} \mathrm{S}$ (e.g. Willson and Rees, 2000). Inspection of AVHRR seasurface temperature (SST) images and numerical model outputs have revealed that when the $\mathrm{BC}$ leaves the South Brazil Bight, just north of the study area, it may bifurcate into two branches. One branch flows along the $2000-\mathrm{m}$ isobath carrying most of the current volume. A weaker inshore branch flows along the $100-\mathrm{m}$ isobath as a coastal component of the BC. There is evidence of an equatorward seasonal density flow in the inner-shelf zone, which is forced by the 
river runoff further south. This coastal flow may induce the formation of small eddies $(\sim 100 \mathrm{~km}$ radius $)$ through shear instability process (Soares and Möller, 2001; Souza and Robinson, 2004).

The influence of intense mesoscale physical variability on ichthyoplankton distributions has been successfully demonstrated elsewhere. The advection caused by a stationary warm core ring along the Scotian Shelf may have caused a $35-50 \%$ decrease in the abundance of larvae of commercially important fish species, and a slowly moving ring could, in certain conditions, remove most of a year class (Flierl and Wroblewski, 1985). Myers and Drinkwater (1989) found evidence that reduced recruitment in 15 of the 17 groundfish stocks in the Scotian shelf-slope region was associated with increased warm core ring activity.

In the SBS break region, outer SBS, the influence of physical processes on the life cycle of fish has only been indirectly demonstrated (Lima and Castello, 1995). However, these processes can be an important exchange mechanism between coastal and oceanic waters as they alter the specific composition of the ichthyoplankton assemblages. Here we present evidence of an anticyclonic eddy dominating the shelf around $31^{\circ} \mathrm{S}$, and discuss its probable influence on the distribution and composition of the SBS larval fish assemblage. We combine AVHRR imagery, satellite altimetry and in situ hydrographic data to assess the synoptic ichthyoplankton distribution. This approach will improve the knowledge about the mechanisms influencing the ichthyoplankton distribution in the SBS.

\section{DATA AND METHODS}

Hydrography and ichthyoplankton in situ data

During the late 1990s, a field effort took place along the entire Brazilian coast to gather the relevant oceanographic and fishery in situ data to support the establishment of the Brazilian Exclusive Economic Zone (EEZ). From 3 to 20 December 1997 a hydrographic grid of 63 stations from 34 to $28^{\circ} \mathrm{S}$ and between 100- and 2000-m isobaths was sampled (Fig. 1). Based upon the bathymetry of sampled station, three geographical regions were adopted: a continental shelf region along the 100-m isobath; a shelf break along the 200-m isobath; and an oceanic region along the $2000-\mathrm{m}$ isobath. At each station, temperature and salinity data were collected with a Seabird Electronics

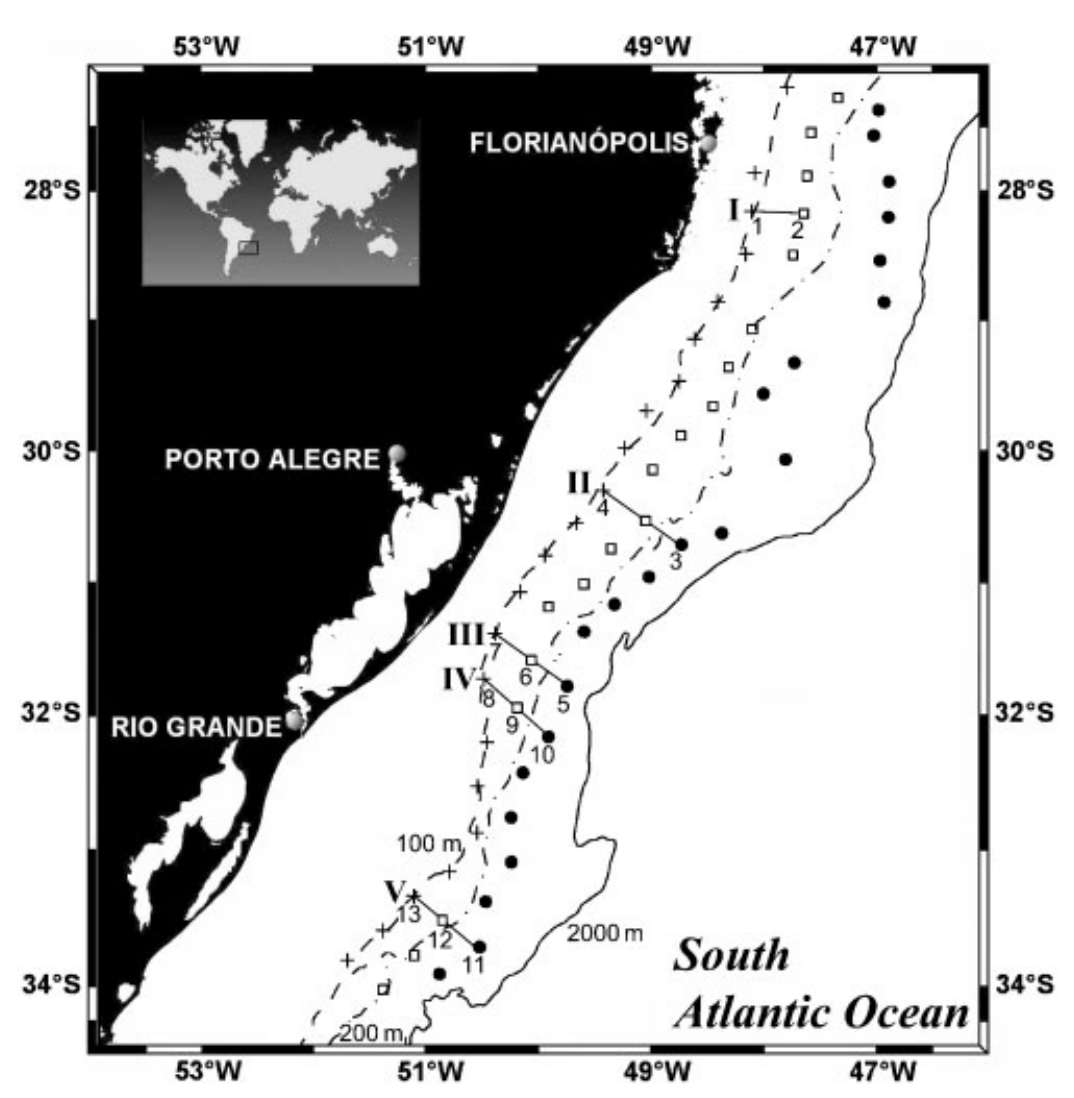

Figure 1. Study area showing the distribution of the hydrographic sampling. The stations were located either along continental shelf $(+)$, the shelf break $(\square)$, or in deeper, oceanic waters $(\bullet)$. The five cross-shelf transects where ichthyoplankton samples were collected are also indicated.

(C) 2006 Blackwell Publishing Ltd, Fish. Oceanogr., 15:1, 37-43. 
model 19 CTD. Dynamic heights $\left(\Phi_{0 / 80 \mathrm{~m}}\right)$ were calculated according to Pond and Pickard (1986) for the stations along the continental shelf. Fish eggs and larvae were collected at 13 stations deployed at five cross-shelf transects. To obtain these samples a $70-\mathrm{cm}$, $300-\mu \mathrm{m}$ mesh Bongo net equipped with a flowmeter was towed obliquely. Oblique tows were taken from the top $200 \mathrm{~m}$, or from the bottom in shallower waters. All material was fixed in $4 \%$ formalin, sorted and identified to the family level under a dissecting microscope.

\section{Satellite data}

This study uses the combination of altimetry data, collected by the T/P and ERS-1/2 satellites, and SST obtained by the Advanced Very High Resolution Radiometer (AVHRR) sensor onboard of the NOAA$12 / 14$ satellites. All data sets are concurrent with the time of the in situ observations.

The combined altimetry data from the different satellites (T/P + ERS-1/2) were merged in the form of Maps of Sea Level Anomalies (MSLA) relative to a long-term mean. The processing and validation of the data set were performed by the AVISO ${ }^{1}$ Project, the oceanographic satellite data bank of the French space agency Centre National d'Estudes Spatiales (CNES). The MSLA are calculated every 10 days (matching the $\mathrm{T} / \mathrm{P}$ orbital repeat period) and have a horizontal resolution of $0.25^{\circ} \times 0.25^{\circ}$.

Because of the relatively high spatial resolution $(1.1 \times 1.1 \mathrm{~km})$, the SST cloud-free images are useful for identifying meanders and eddies, especially in frontal regions like the SBS. Thus, some SST images from the cruise period were acquired and analysed at the Remote Sensing Laboratory - Fundação Universidade Federal do Rio Grande (FURG).

\section{RESULTS AND DISCUSSION}

Hydrography and ichthyoplankton in situ observations

The warmest shallow water in the region, the Tropical Water (TW) which is part of the southward flowing $\mathrm{BC}$, has temperature and salinity higher than $18.5^{\circ} \mathrm{C}$ and 36 , respectively (Campos et al., 1995). The TW is found immediately above the South Atlantic Central Water (SACW, $6-20^{\circ} \mathrm{C}$ and 34.5-36). Subtropical Shelf Water (STSW), which is described as a modified SACW diluted by

\footnotetext{
${ }^{1}$ AVISO Project (Archive, Validation et Interpretation des donnes des Satellite Oceanographiques) website address: http://www.aviso.oceanobs.com

continental runoff from the coast of Brazil (Piola et al., 2000), is observed over the shelf and shelf break, mainly south of $32^{\circ} \mathrm{S}$. In the northern region (cross-shelf transects I and II), the upper layer on the continental shelf was occupied by STSW and TW, while SACW was found in deeper layers (Fig. 2). At stations in these two northern transects, fish larvae within the families Myctophidae, Bregmacerotidae, Clupeidae, Synodontidae and Engraulidae were most abundant. The thermohaline characteristics of the Coastal Water (CW) vary according to the annual cycle of river runoff and mixing with offshore waters (Ciotti et al., 1995). In the southern continental shelf (cross-shelf transects III, IV and V), the intrusion and mixing of coastal and subtropical waters was observed, and larvae of Engraulidae and Bregmacerotidae were the most abundant at those stations (Fig. 2).

Analysis of the in situ data revealed an anticyclonic structure dominating the shelf around $31^{\circ} \mathrm{S}$. Hydrographic data suggest that this feature is centred on the 80-m isobath, with a characteristic spatial scale of $200 \mathrm{~km}$, evident from the density field along continental shelf between 400 and $600 \mathrm{~km}$ (Fig. 3). The dynamic height $\left(\Phi_{0 / 80 \mathrm{~m}}\right)$ distribution along the continental shelf reveals a $0.07-\mathrm{m}$ dome-like structure centred at station 7 (cross-shelf transect III, Fig. 3). The analysis of the ichthyoplankton samples showed that the abundance of fish larvae is lowest at the centre of this structure and higher on its edge. Increased dynamic height gradients indicate strong geostrophic currents that would lead to advection of water masses around the eddy. The T-S diagram of station 7 (section III, Fig. 2) shows that the surface layer of the continental shelf was dominated by $\mathrm{CW}$ and STSW. Engraulidae, Bregmacerotidae and Carangidae were the only fish larvae found in this shelf station. Engraulidae larvae were identified as Engraulis anchoita, a pelagic species often occurring in this region when hydrographic features create areas of high retention (Vasconcellos et al., 1998; Franco and Muelbert, 2003). This was the most abundant species found in the centre of the eddy (Fig. 2), which corresponds to a dynamic height of $\sim 0.32$-m (Fig. 3).

\section{Satellite imagery}

The results from the altimetry data agree quite well with dynamic calculations, suggesting an anticyclonic circulation pattern associated with the eddy observed around $31^{\circ} \mathrm{S}$ (Fig. 4a). The MSLA data reveal a high level of eddy activity in the area, with the succession of high and low sea-level anomalies on the continental 
Figure 2. Larvae abundance (ind./100 $\mathrm{m}^{3}$ ) of the identified families collected in the samples of continental shelf stations that are numbered as well as respective cross-shelf transects from I to V (to the left). The T-S diagrams represent the cross-shelf transects, respectively. The continental shelf temperature-salinity values are indicated as crosses $(+)$, the shelf-break samples are indicated as squares $(\square)$ and the oceanic region are indicated as dots $(\bullet)$. STSW, Subtropical Shelf Water; TW, Tropical Water; SACW, South Atlantic Central Water; AIW, Antarctic Intermediate Water. The $\sigma_{\mathrm{T}}$ lines are shown at $1 \mathrm{~kg} \mathrm{~m}^{-3}$ intervals.

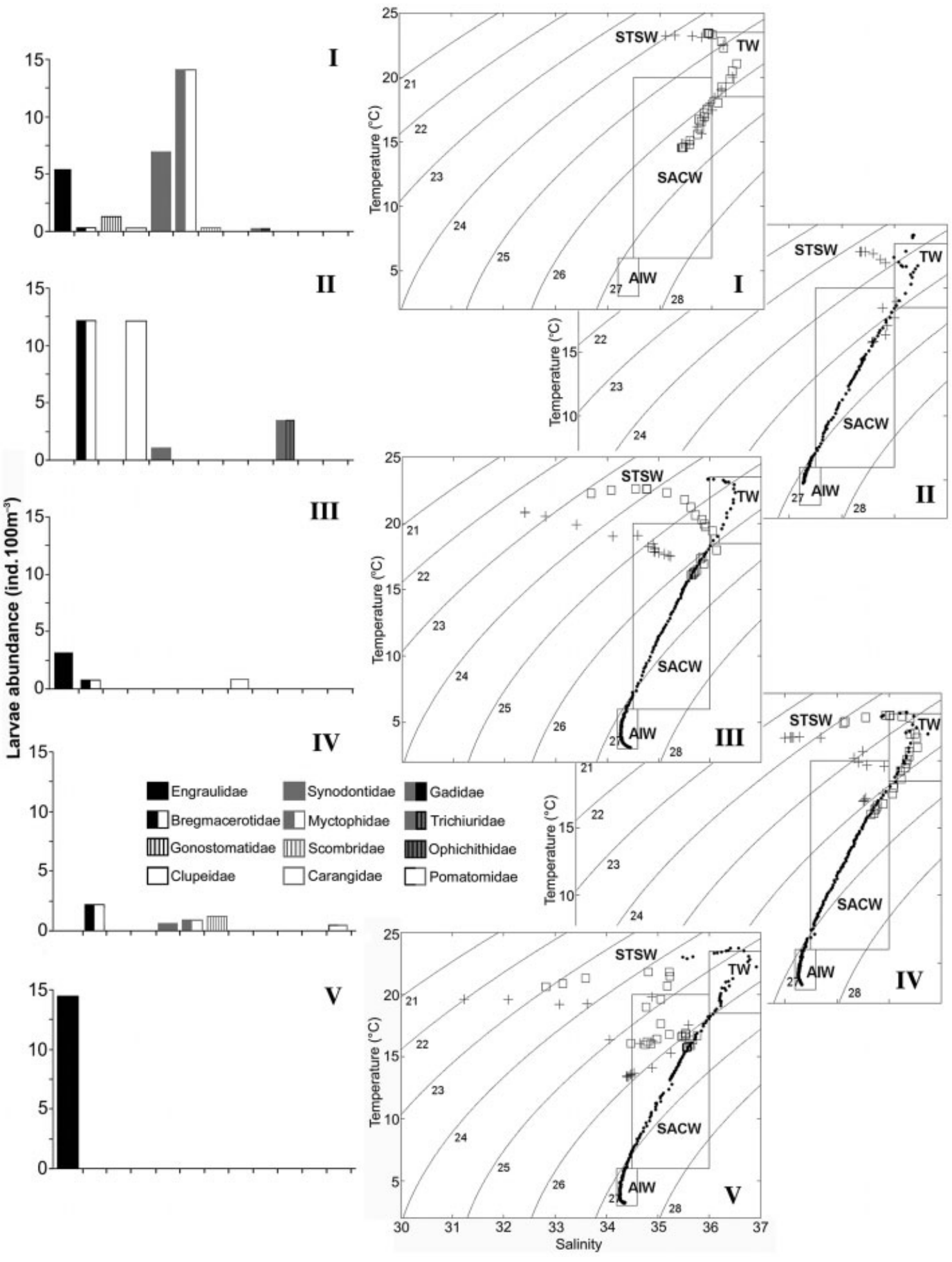

(c) 2006 Blackwell Publishing Ltd, Fish. Oceanogr., 15:1, 37-43. 
Figure 3. Panel showing temperature $\left({ }^{\circ} \mathrm{C}\right)$, salinity and density $\left(\right.$ as $\left.\sigma_{\mathrm{T}} ; \mathrm{kg} \mathrm{m}^{-3}\right)$ fields along stations for the continental shelf, respectively from the upper panel. Each hydrography station is represented as a solid inverted triangle. The lower panel shows the dynamic heights $(\mathrm{m})$ of the stations along continental shelf represented by dots $(\mathbf{O})$ and the abundance of fish larvae (ind. $/ 100 \mathrm{~m}^{3}$ ) by crosses $(+)$. The shelf stations of each cross-shelf transect represented in Fig. 1 are numbered from I to V. The arrows represented a schematic illustration of the eddy rotational movement. The onshore flows that probably occur to the north of the eddy can transport fish larvae of slope-water origin onto the shelf, while the offshore flows dragged coastal cold water by the rotational movement to the south of the eddy.
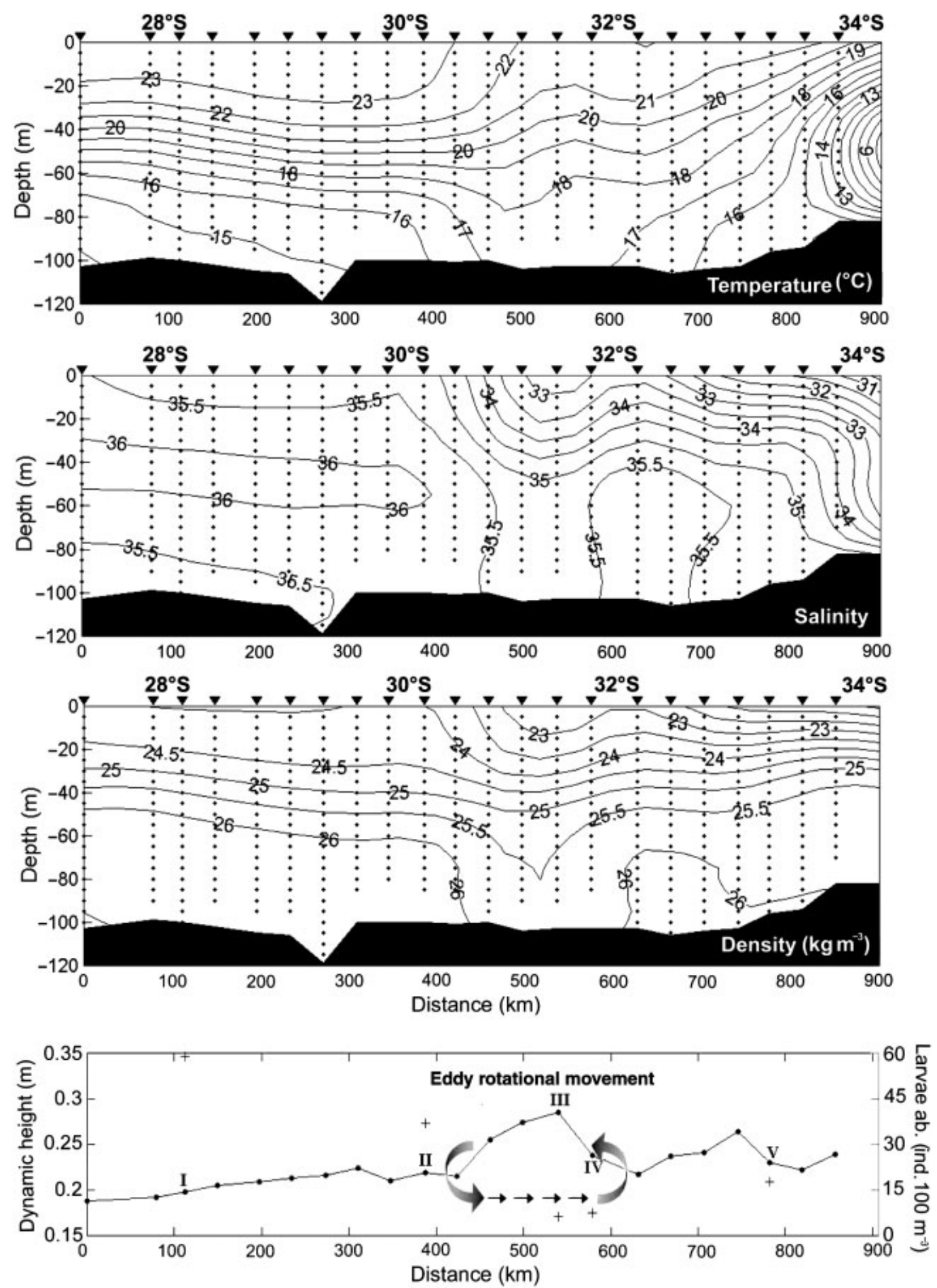

(C) 2006 Blackwell Publishing Ltd, Fish. Oceanogr., 15:1, 37-43. 
Figure 4. (a) Mapped sea-level anomaly $(\mathrm{m})$ produced from TOPEX/POSEIDON and ERS altimetry data. Negative anomalies are represented by dashed lines (values $\leq 0 \mathrm{~m}$ ) and positive anomalies are represented by a solid line. (b) Sea-surface temperature produced from AVHRR measurements made by NOAA-12 satellite showing the bifurcation of the Brazil Current. The stronger branch is shown by a solid arrow and the inshore one is shown by a dashed arrow. SST field image for 9 December 1997 (provided by Remote Sensing Laboratory - FURG).

(a)

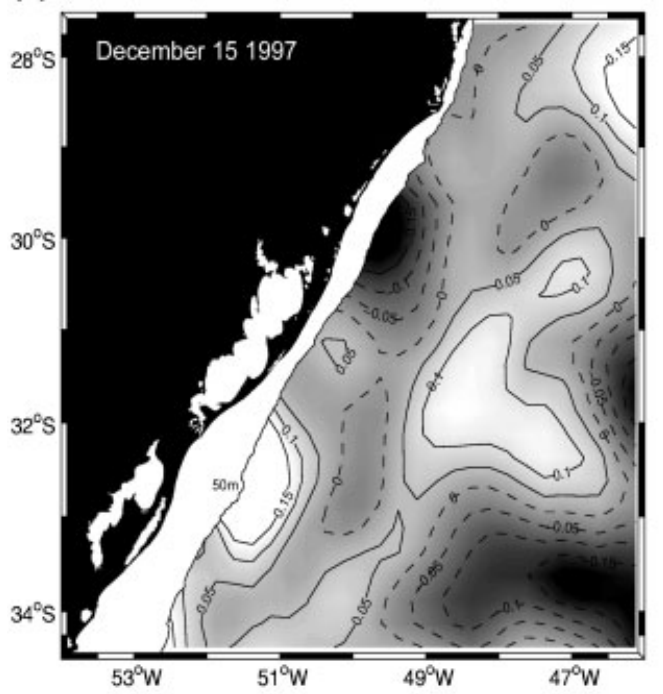

(b)

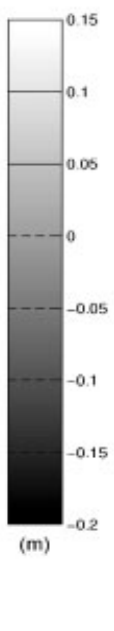

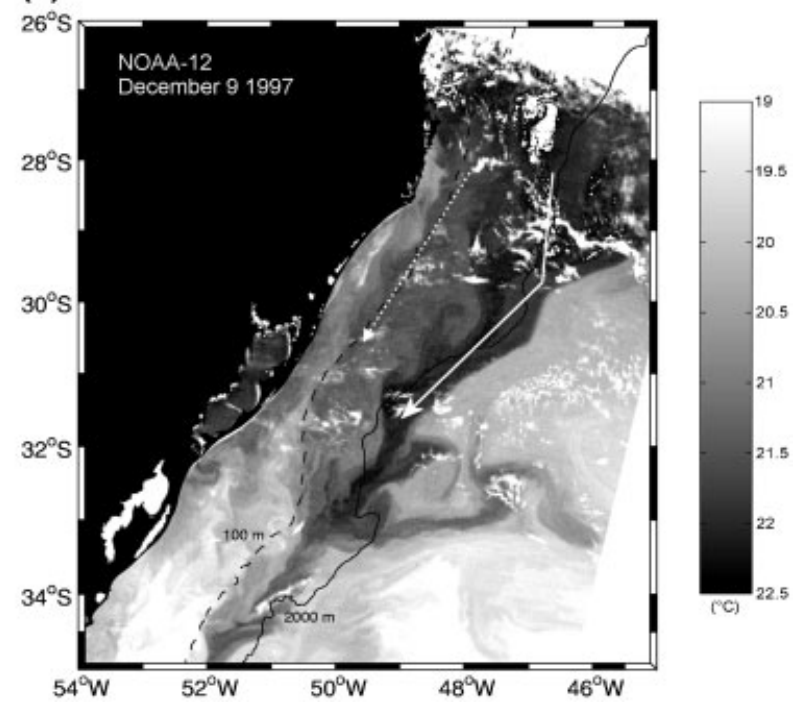

ACKNOWLEDGEMENTS

The members of the Ichthyoplankton Ecology Laboratory and Physical Oceanography Laboratory (FURG), made possible the accomplishment of this project. Y.V.B. Sarma and M.C. Vasconcellos provided helpful comments on an earlier draft of the manuscript. The in situ data were provided by REVIZEE (SCORE-Sul), a program supported by the Brazilian Federal government (MMA and SECIRM). This research benefited from grant 478788/01-0 of the Brazilian Research Council (CNPq). BCF was supported by PIBIC $\mathrm{CNPq} /$ Furg Scholarship, and JHM by a CNPq research Fellowship (grant 305969/03-0).

\section{REFERENCES}

Campos, E.J.D., Gonçalves, J.E. and Ikeda, Y. (1995) Water mass characteristics and geostrophic circulation in the South Brazil Bight - Summer of 1991. J. Geophys. Res. 100:1853718550.

Castello, J.P. and Haimovici, M. (1991) Simpósio da FurG sobre pesquisa pesqueira: comentários e recomendações. Atlântica 13:5-9.

Ciotti, A.M., Odebrecht, C., Fillmann, G. and Möller, O.O. (1995) Freshwater outflow and subtropical convergence influence on phytoplankton biomass at the southern Brazilian continental shelf. Cont. Shelf. Res. 15:1737-1756.

Flierl, G.R. and Wroblewski, J.S. (1985) The possible influence of warm core Gulf Stream rings upon shelf water larval fish distribution. Fish. Bull. 83:313-330. 
Franco, B.C. and Muelbert, J.H. (2003) Distribuição e composição do ictioplâncton na quebra de plataforma do Sul do Brasil. Atlântica 25:75-86.

Goni, G., Kamholz, S., Garzoli, S. and Olson, D. (1996) Dynamics of the Brazil-Malvinas Confluence based on inverted echo sounders and altimetry. J. Geophys. Res. 101:16273-16289.

Haimovici, M., Pereira, S. and Vieira, P.C. (1989) La pesca demersal en el sur de Brasil en el período 1975-1985. Frente Maritimo 5:151-163.

Heath, M.R. (1992) Field investigations of the early life stages of marine fish. Adv. Mar. Biol. 28:1-174.

Hunter, J.R. and Alheit, J. (1997) International GLOBEC Small Pelagic Fishes and Climate Change program. Implementation Plan. GLOBEC Rep. 11:1-36.

Krug, L.C. and Haimovici, M. (1991) Análise da pesca da enchova, Pomatomus saltatrix no Sul do Brasil. Atlântica 13:119-129.

Lima, I. and Castello, J.P. (1995) Distribution and abundance of South-west Atlantic anchovy spawners (Engraulis anchoita) in relation to oceanographic processes in the southern Brazilian shelf. Fish. Oceanogr. 4:1-16.

Lima, I.D., Garcia, C.A.E. and Möller, O.O. (1996) Ocean surface processes on the southern Brazilian shelf: characterization and seasonal variability. Cont. Shelf Res. 16:13071317.

Loder, J.W., Boicourt, W.C. and Simpson, J.H. (1998) Overview of western ocean boundary shelves. In: The Sea, Vol. 11. A.R. Robinson \& K.H. Brink (eds), John Wiley and Sons, New York, pp. 3-27.
Matsuura, Y. and Kitahara, E.M. (1995) Horizontal and vertical distribution of anchovy Engraulis anchoita eggs and larvae off Cape Santa Marta Grande in southern Brazil. Arch. Fish. Mar. Res. 42: 239-250.

Muelbert, J.H. and Sinque, C. (1996) Distribution of bluefish (Pomatomus saltatrix) larvae in the southern Brazilian continental shelf. Mar. Freshw. Res. 47:311-314.

Myers, R.A. and Drinkwater, K. (1989) The influence of Gulf Stream warm core rings on recruitment of fish in the northwest Atlantic. J. Mar. Res. 47:635-656.

Peterson, R.G. and Stramma, L. (1991) Upper-level circulation in the South Atlantic Ocean. Prog. Oceanogr. 26:1-73.

Piola, A.R., Campos, E.J., Moller, O.O., Charo, M. and Martinez, C. (2000) Subtropical Shelf Front off eastern South America. J. Geophys. Res. 105:6565-6578.

Pond, S. and Pickard, G. (1986) Introductory Physical Oceanography, 2nd edn. Oxford: Pergamon Press.

Soares, I. and Möller, O. (2001) Low-frequency currents and mass spatial distribution on the Southern Brazilian shelf. Cont. Shelf Res. 21:1785-1814.

Souza, R.B. and Robinson, I.S. (2004) Lagrangian and satellite observations of the Brazilian Coastal Current. Cont. Shelf Res. 24:241-262.

Vasconcellos, M.C., Freire, K.F. and Castello, J.P. (1998) Distribution patterns and feeding success of anchovy, Engraulis anchoita, larvae off southern Brazil. Sci. Mar. 62:385-392.

Willson, H.R. and Rees, N.W. (2000) Classification of mesoscale features in the Brazil-Falkland Current confluence zone. Prog. Oceanogr. 45:415-426. 